\title{
Regulating Volunteering: Lessons From The Bingo Halls.
}

Kate D. Bedford

Kent Law School, University of Kent, Canterbury, Kent, UK CT2 7NS.

Tel: +44 1227824868

Email: k.bedford@kent.ac.uk

Dr. Kate Bedford (k.bedford@kent.ac.uk) is a Reader in Law at Kent Law School, University of Kent. She is currently the principal investigator on an ESRC-funded research project into bingo regulation (ES/J02385X/1, A Full House: Developing A New Socio-Legal Theory of Global Gambling Regulation). Funding for the research presented in this article was provided by the Faculty Research Fund of the University of Kent and by the Alberta Gaming Research Institute (A Case Study of Bingo Regulation in Alberta, 2012). The author would like to thank the generosity of the interviewees who contributed to the case studies. She also acknowledges the support of Rianne Mahon, Donna Coghill, the faculty and students at the Institute of Political Economy at Carleton, Garry Smith, and Courtney Petruik. Comments from Donatella Alessandrini, Colin Campbell, Davina Cooper, Judy Fudge, Emily Grabham, Toni Williams, and four anonymous reviewers were invaluable to the development of the argument presented here. 


\begin{abstract}
This article uses charitable bingo to explore the socio-legal regulation of volunteers. Using case studies of two provincial bingo revitalization initiatives in Canada, I explore how charities and government officials manage the tension between regulating and incentivizing volunteers. I show that bingo revitalization plans in Alberta and Ontario increased surveillance of non-regularized workers and failed to protect charity service users from unpaid labor requirements. Moreover, revitalization initiatives reframe the volunteer role to focus on customer service and explaining how charities benefit the community. The potential for bingo volunteering to promote spaces of mutual aid with players will thus likely decline. I suggest that the allied power of charity and state over unpaid workers is increasing, giving charities better-protected interests in volunteer labor and changing the tasks that volunteers do. The need for more research exploring the interests of volunteers as regulatory stakeholders in their own right is thus pressing.
\end{abstract}




\section{INTRODUCTION}

Our products support local needs and local people. Charitable gaming allows communities to have fire and rescue vehicles, parks and playgrounds; it allows kids to play sports, go to camp and discover art and music; it helps parishes provide quality education; it builds community centers, funds programs for senior citizens, and the physically and mentally challenged; and it provides much needed services to our veterans and military families. (National Association of Fundraising Ticket Manufacturers [NAFTM] 2010, 3)

It's harder and harder to get volunteers.... You know you got to kind of bully them into it. (Bingo hall manager, Alberta)

In 2001 the United Nations celebrated the year of the volunteer. In 2006 the European Volunteer Centre launched a Manifesto for Volunteering. Although the use of volunteers during the UK's 2012 Jubilee holiday was controversial, ${ }^{1}$ their deployment in the 2012 London Olympics was central to the successful marketing of the games as a collective national endeavor. The US government's website contains a page on "public service and volunteerism" which lists tips for charitable giving alongside paid job opportunities in Iraq's reconstruction effort and advice on joining the armed forces (US Government 2014). Such widespread reliance on, and promotion of, volunteering means that it is an urgent priority for researchers to investigate how volunteers are constituted and regulated. While research on the non-profit sector often imputes economic value to 
volunteer labor time (see Ministry of Government Services 2007 on Canada) and there is a sizeable literature on volunteer motivations (see summary in Musick and Wilson 2008), we know relatively little about the socio-legal regulation of volunteer labor. This is despite the fact that, as Debra Morris pointed out many years ago, "there is increased legal encroachment into the regulation of volunteering" (1999a, 113).

I seek to contribute to this research agenda by exploring how volunteers are regulated in a key sector of charitable gaming activity. Although for-profit casinos are often positioned as the globally salient form of gambling in neoliberal times, charitable gaming is in fact "the most widespread form of legalized gambling" (Dolan and Landers 2006, 6) in many jurisdictions, including the United States. In 2004 the estimated gross receipts from charitable gaming in the 46 states (plus DC) that permit it exceeded US\$7 billion (Christensen et al. 2009, 218) and in 2010 charities in Minnesota, Texas, and Michigan reported, respectively, revenues of US\$973 million; \$700 million, and \$560 million from charitable gaming (NAFTM 2010, 7). Charitable gaming can include small lotteries, bingo, break open tickets, raffles, and "Monte Carlo" nights allowing card games and roulette.

Of these, bingo is perhaps the paradigmatic example of how gambling can involve fundraising for good causes. Bingo is a lottery-style game where players cross numbers, called randomly by a caller, off a purchased ticket to form patterns and win prizes. In 2010 gross receipts from bingo were CAN\$609 million in Ontario, \$140 million in Alberta; and \$44 million in Manitoba (NAFTM 2010, 8). More Albertans report playing bingo than casino table games ${ }^{2}$ and a weekly radio bingo game run by an Aboriginal 
station within the province made total sales in 2011-2012 of over CAN\$1.5 million enough, they hope, to fund new transmitters. Yet the game, and the volunteers who sustain it across much of North America, remain understudied.

This article focuses on what charitable bingo reveals about volunteer regulation. I explore how volunteers in Canadian bingo games are defined, monitored, disciplined, and incentivized and how their interests do - or do not - feature in provincial government initiatives designed to revitalize bingo halls in the face of competition from other gambling sectors. I focus on local charity volunteers, municipal bingo inspectors, and what Mariana Valverde (2011) calls the "the lowly legal mechanism of licensing" (297) as a pathway into understanding voluntarism. In winter 2011 I conducted twenty-eight interviews (twenty-six recorded and transcribed) in Ontario with a mix of provincial government policymakers, bingo inspectors, suppliers, hall managers, volunteer coordinators, volunteers, presidents of charitable bingo hall associations, and bingo industry representatives. In summer 2012 I repeated the study in Alberta, conducting twenty-seven interviews (twenty-three recorded and transcribed) with the same mix of stakeholders. I also played bingo in halls across both provinces, speaking with players, volunteers, and staff.

I organize the findings from this research into five sections. Section 1 introduces the analytic framework used to explore voluntarism, highlighting the importance of states and charities as rule-makers and the need to explore volunteers' own understandings of their labor. Section 2 explains the context of the case study, laying out the legal framework for charitable gaming in Canada and introducing the bingo revitalization 
efforts undertaken in Alberta and Ontario. I progress in Section 3 to explain the rules governing bingo volunteers and the key tension between surveillance and incentivization of unpaid work evident in regulatory reform initiatives. Two solutions to this tension have emerged from Alberta's and Ontario's bingo reforms: (a) using alternative currency systems ("bingo credits") to incentivize unpaid work (Section 4) and (b) reorganizing volunteer tasks so as to distance volunteers from players (Section 5). I conclude with some lessons that this case study of bingo might hold for those interested in the sociolegal regulation of voluntarism. I suggest that the allied power of charity and state over unpaid workers is increasing, giving charities better-protected interests in the fruits of volunteer labor and changing the tasks that volunteers are being asked to do in ways that threaten to undermine mutual aid practices. The need for more research exploring the interests of volunteers as regulatory stakeholders in their own right is thus pressing.

\section{SECTION 1: ANALYSING VOLUNTARISM.}

The study of volunteer tasks stands at the frontier of research on volunteering. (Musick and Wilson 2008, 418)

Formal volunteering is a subset of unpaid work, usually distinguished from other types on the grounds that it is done without compulsion, for organizations (as opposed to informally, for family and friends). Notoriously difficult to define, it can involve service initiatives to help the less fortunate; mutual aid, self-help, and activist campaigning work; and leisure activities such as participation in sporting events or support for the arts 
(Rochester, Paine, and Howlett 2010, 15). The boundaries separating volunteering from activism, and from care, are much debated (Wilson 2000, 2012; Musick and Wilson 2008).

Volunteering has long been important to debates about politics, social life, and national identity, especially in North America where voluntary associations have been key to discussions of civic engagement and democracy (Sills 1957; Kramer 1981; Skocpol 2003). However, interest in volunteering has proliferated and intensified recently. The leading collection on the field identifies a "globalization of volunteering" (Musick and Wilson 2008, 533) and a growing international consensus that the number of people willing to do voluntary work is a "barometer of a society's civic health" (370). Governments in many countries, and of many political persuasions, have turned to volunteers as routes to secure trust, community revival, popular participation, social cohesion, employability, empowerment, democratic legitimacy, economic efficiency, physical and mental health, and crime-reduction. ${ }^{3}$ The weight of expectation placed on voluntary action is greater than ever (Rochester, Paine, and Howlett 2010, 1).

The proliferation and intensification of policy interest in volunteering is linked to the widespread restructuring of government relationships with the third sector in many countries. As charitable and non-profit organizations have increased their involvement in welfare provision, calls have emerged for closer, more formalized partnership relations with the state. A range of regulatory experiments have been enacted, including compacts, new regulatory agencies, new charity legislation, new legal forms for the incorporation of third-sector organizations, more extensive use of the tax system to support charities, and 
new self-regulatory schemes on governance and fundraising (S. Phillips and Smith 2011, 1-2; S. Phillips 2012). ${ }^{4}$ For example, in 2001 Canada's federal government established a Voluntary Sector Initiative to strengthen the charitable sector's capacity, including via increased self-regulation. ${ }^{5}$ In 2011 the sector's representative body, Imagine Canada, launched a hallmark-style certification scheme for good governance, along with new guidelines on fundraising.

Two, inter-related concerns have emerged as a result of such trends. First, many observers raise the specter of state capture of third-sector goals, with governments promoting the types of voluntary work that mostly closely fit their own political agendas (Dunn 2008; Musick and Wilson 2008; Rochester, Paine, and Howlett 2010). This is likely to disadvantage organizations with a more campaigning, activist orientation (INCITE! 2007; Musick and Wilson 2008, 523).

Second, there is increasing concern about the need to "defend the spirit of volunteering from formalisation" (Rochester, Paine, and Howlett 2010, 220). Although the bureaucratization and "oligarchic management" (Skocpol 2003, 11) of volunteer labor has long been a concern within the sector, ${ }^{6}$ current state initiatives have been associated with the growing dominance of business models of organizational performance and the professionalization of volunteer management and training. This is manifest in screening, job descriptions, quality standards, formal reviews and appraisals, and even disciplinary procedures (Morris 1999b; Musick and Wilson 2008). Rochester, Paine, and Howlett (2010) refer to this as a "workplace model" of volunteer management, involving an emphasis on the efficient use of volunteer resources (151). As they note, the impact of 
these changes within smaller mutual-aid style groups is potentially very large, since volunteers may be reframed as a resource to be used rather than as stakeholders or coowners (230). Formalization also affects the relationship between volunteers and service users, since emphasis may be placed on meeting targets defined by government rather than offering the types of support required by users. They conclude that a key challenge for the future involves "defending the independence of volunteering from interference and colonisation by the state" (239).

Debates about mandatory volunteering are central in this respect, drawing together concerns about state capture and formalization. The always fuzzy boundary between choice and coercion - long central to literature on volunteer motivation - has been rendered fuzzier still with new trends towards employer-supported volunteering, alternative sentencing volunteering, compulsory service learning by students, the expanding use of internships for young people seeking training and access to paid work, and "workfare" for the unemployed (Horne and Maddrell 2002; Musick and Wilson 2008; Rochester, Paine, and Howlett 2010; Wilson 2012; Stewart and Owens 2013). Indeed in their chapter on maintaining the independence of voluntary action Rochester, Paine, and Howlett (2010) argue that "the most immediate or direct challenge is the possibility of government making some forms of volunteering compulsory" (211).

In this article, I aim to contribute to these debates about state capture and formalization of volunteer labor, including via mandated volunteering, by offering a case study of how volunteers are regulated and incentivized in a key, under-researched arena of social life: bingo halls. My approach is underpinned by two inter-linked analytic 
commitments: (1) the need for critical interrogation of states and charities as rule-makers and (2) the need to prioritize volunteers as stakeholders in their own right. I elaborate each in turn, before linking this approach to bingo.

\section{States and Charities as Rule-Makers}

Attention to the state's legal regulation of unpaid work is long-standing in a range of sub-fields, including labor law, welfare law, and charity law (Morris 1999a and b; Dunn 2000; J. Phillips, Chapman, and Stevens 2001). Legal battles over (in)voluntary work have also become key features of welfare state restructuring in several countries. ${ }^{7}$

However, charities themselves are also key actors in making and interpreting rules about volunteering. While charities have often relied on, and acted in partnership with, states and businesses, ${ }^{8}$ they have also pursued their own interests in ways that require critical interrogation. For example, in her history of the inter-connection between Catholic charities and state agencies in Toronto, Paula Maurutto (2003) questions the simplistic idea of charities as the preserve of private bodies, given that they have relied on significant public subsidies, including government financing and legislative support, from the 1820s. Using Callon's concept of interessement (where networks of actors are established not just because of legal or institutional ties of dependencies but because participants come to construe their problems in allied ways and see their fates as bound together), Maurutto shows that Catholic charities pursued their own interests through work with the state, including moralizing the poor via mandating work and stemming communism (Maurutto 2003, 12-13; see also Rekart 1993; Tillotson 2008). 
Moreover, notwithstanding the important role of court decisions, policy, and charity legislation, the broader context to volunteering motivation is also crucially structured by charities themselves and their internal organizational rules, procedures, and practices (Sills 1957; Wuthnow 1991; Wilson 2000). As Musick and Wilson (2008) put it:

Volunteer administrators face a dilemma: they must foster the volunteer spirit of those who have offered their services for free, but they must also control that spirit to meet organizational needs. They want to energize their volunteers but also to discipline them, and they are denied many of the methods of energizing and controlling available to people who manage paid employees. (429) Hence they urge paying attention to the details of how volunteer work is organized in specific contexts. This entails seeing both states and charities as rule-makers.

\section{Centering Volunteers as Stakeholders.}

Secondly, it is essential to center volunteers analytically as stakeholders in their own right. Typically when volunteers have appeared on the radar of mainstream legal study, other actors have claimed to be representing their interests. Occasionally, governments have taken legal action against charities to stop abuse of volunteers. ${ }^{9}$ When volunteers themselves have asserted rights, charities have often responded with concern. ${ }^{10}$ For example, much debate on volunteers in Canada concerns the fear that charities (and businesses) might inadvertently treat volunteers in such a way that they can claim employee status. ${ }^{11}$ Some charities also fear that human rights legislation imposes 
too high a level of protection for volunteers against alleged discrimination. ${ }^{12}$ In addition, many charities are concerned about their liability for vicarious torts stemming from volunteer behavior; in Canada volunteer screening is being promoted as a federal response (Volunteer Canada/Public Safety Canada 2012). In none of these realms are volunteers themselves usually considered to have independent status as stakeholders in the regulations that govern them.

In the charitable gaming sphere specifically, many legal disputes have involved disagreements between businesses, charities, and regulators over how to distribute proceeds. ${ }^{13}$ If volunteers are visible at all in this realm, it is as potential threats to charities. For example, in an early analysis of charitable exemptions from gambling prohibitions in Ohio, Ravenscraft and Reilly (1977) offered a five-part proposal for law reform, including that the volunteers who operated charitable bingo be more strictly monitored via licensing (to ensure that they were active members of the sponsoring organization); pre-screening (to ensure that no former gambling offenders were involved); and state-issued identification badges (Ravenscraft and Reilly 1977, 708, 71619). Such initiatives would help ensure that "bona fide charities [will] be assured of maximum benefit from the games which are operated in their name" (729). ${ }^{14}$

The issue I wish to explore, in contrast, is what contemporary regulatory reforms in bingo mean for volunteers and what this in turn might tell us about the everyday political economic landscapes of volunteering being created in restructuring welfare states. In this regard, I draw from research on the diverse meanings that volunteering holds for those who engage in it (Sills 1957; Pearce 1993; Horne and Maddrell 2002; 
Musick and Wilson 2008; Wilson 2012) and the social relations made possible, and challenged, by philanthropic mobilization of labor. Attentiveness to the production and regulation of different kinds of voluntary spaces - especially unglamorous, mundane spaces of voluntarism - can be especially useful here (Milligan and Conradson 2006). While some forms of voluntarism involve wealthy people engaging in a form of poverty tourism, temporarily trying out new roles such as food server in a homeless shelter or amateur shop keeper (Prochaska 1977), volunteering can also provide a source of adventure and rebellion and opportunities to travel, form intimate communities with likeminded people, and express political opinions (Mahood 2009). Kenneth Maes's (2012) interviews with unpaid carers for people living with HIV/AIDS in Addis Ababa found that their motivations ranged from reducing suffering and pleasing God to desires for direct remuneration (such as food), new knowledge, patron-client relationships, and paid job opportunities in a context of widespread unemployment and poverty (55). The organizations that mobilize these volunteers try - never entirely successfully - to shape such motivations, via guidelines, training, and volunteer initiation and celebration ceremonies.

Many others have explored this process of negotiation, involving a mix of organizational appeals to intrinsic rewards and the use of material incentives (Pearce 1993; Musick and Wilson 2008); of organizational efforts to direct unpaid work and of volunteers' unpredictable, unreliable, "shaggy, untidy and anarchic" responses (Rochester, Paine, and Howlett 2010, 241). For example Liz Parsons's (2006) research on charity shop volunteers offers a useful analysis of how the meaning of unpaid labor 
can be impacted by shifts in regulatory approach, themselves related to political economic trends. She found that UK charity shops created spaces for sociality and belonging in the local community, especially for older women volunteers (see also Horne and Maddrell 2002). Those volunteers saw the main beneficiaries of their labor as the shoppers (local poor people who were in need of a bargain), rather than those abroad that the charity was aiding through its global humanitarian activities. This localized ethos of helping people with whom there was a perceived common bond was harmed as charities moved to professionalize the shops, making them more like work sites with paid managers at head office levels, increasing standardization of displays, and, in some cases, a move to uniforms and/or name badges (231).

In a very different context, Jacinthe Michaud (2004) researched the impact that Ontario's workfare policy had on poor women who were already volunteering for feminist and community groups. Those women had volunteered for many reasons, including to help secure resources for their children, to avoid social exclusion, to connect with people who shared their political values, and to be in spaces that they experienced as comparatively free of sexism, racism, xenophobia, and anti-Francophone prejudice (274). Many considered their non-waged work to be political activism (273). All reported that the implementation of workfare (see n9) transformed these varied, nuanced meanings of volunteering, giving rise "to a new economy of authoritarian working conditions within the community sector" (287-88).

The argument that follows is indebted to this type of research into how shifts in regulatory approach effect volunteer motivations and experiences. It examines in depth 
how charities and provincial regulators try to manage the tension between regulating and incentivizing the volunteers who sustain bingo and what this means for volunteers themselves.

\section{SECTION 2. THE LEGAL AND POLITICAL FRAMEWORK OF CHARITABLE BINGO REGULATION IN CANADA.}

Bingo is intriguing, for many reasons. In North America the game has a distinctive demographic of older working-class female players (Morton 2003; Paarlberg et al. 2005; White, Rogers Brown, and Dowd 2010) and a long connection with struggles for indigenous sovereignty over economic development. ${ }^{15}$ In addition, as a key form of charitable gambling, bingo directs our attention to charities, volunteers, and the complex mix of virtue and vice involved in gambling liberalization debates. As Sytze Kingma $(2008,448)$ argues, gambling liberalization is often reliant on the "charitable alibi" that the money raised will go to worthy causes. Bingo is the paradigmatic site for this regulatory intersection between playful speculation and good works.

In turn Canada is an excellent site for research into charitable bingo. Charities play a key role in gambling in Canada and several provincial governments have tried to revitalize bingo games by forging more collaborative relationships with charities. Part VII of the Canadian Criminal Code (RSC, 1985, c. C-46) criminalizes individuals found gambling and betting, alongside those who offer gambling, promote or advertise gambling, or supply gambling devices (s. 206). The key exemptions for our purposes are as follows: 
207. (1) Notwithstanding any of the provisions of this Part relating to gaming and betting, it is lawful

- (a) for the government of a province, either alone or in conjunction with the government of another province, to conduct and manage a lottery scheme in that province, or in that and the other province, in accordance with any law enacted by the legislature of that province;

- (b) for a charitable or religious organization, pursuant to a licence issued by the Lieutenant Governor in Council of a province or by such other person or authority in the province as may be specified by the Lieutenant Governor in Council thereof, to conduct and manage a lottery scheme in that province if the proceeds from the lottery scheme are used for a charitable or religious object or purpose.

In an important limitation on charitable gambling activity, s. 207 (4) (c) reserves to provinces the authority to run a legal lottery game "operated on or through a computer, video device or slot machine." Hence charities are prohibited from conducting and managing games of chance that are computer-reliant (such as electronic bingo): such games have to be run by the province, under s.207 (1) (a).

In its traditional, paper form bingo is conducted largely under the s.207 (1) (b) exemption on charitable gaming, under which licensed charities and religious organizations use the proceeds for approved charitable purposes. Canada initially followed the criteria for charitable purposes contained in the preamble to the Charitable Uses Act, 1601 (43 Eliz. 1 c. 4): advancement of education, advancement of religion, 
relief of poverty, or other purposes beneficial to the community. Although these grounds have been refined, they continue to provide the key guidance for whether an organization can seek a license to conduct and manage a lottery for good causes. ${ }^{16}$

To receive a license for bingo fundraising, charities must use their own volunteers to conduct and manage the gaming. Although bingo funds a wide range of good works, from rape crisis shelters to immigrant support groups, the largest proportion of organizations with bingo licenses are youth sports and recreation organizations. These fall under the fourth category of the standard common-law test for charitable purposes (the catch-all category of "other purposes beneficial to the community"). Depending on the province, the bingo is held either in a hall owned by a private operator, to which charities pay rent; by an association of charities; or by a religious association, charity, or service club licensed to conduct and manage gaming on its own behalf (e.g. a local branch of the Canadian legion). ${ }^{17}$ Usually associations of licensed charities take responsibility for activities such as setting schedules for which charity is responsible for which bingo slot, ${ }^{18}$ dividing and distributing proceeds, and monitoring volunteer attendance.

There is considerable provincial variation in charitable bingo regulation. ${ }^{19}$ For example, Alberta follows a charitable model of gambling policy that professes to make charities the key beneficiaries of all gambling activity. Hence licensed charities can conduct and manage table gaming in casinos, sending their volunteers to work at the casino in exchange for a split of the profits. In 2010-11 3,524 charitable gaming licenses were issued for casinos in the province, while 857 were issued for bingo (Canadian 
Partnership for Responsible Gambling 2012, 5). That said, however, in part because of long waiting lists for casino licenses and in part because casino revenues are uneven, with urban sites raising more revenue than rural ones, bingo remains an important source of regular revenue for many organizations. I spoke with one organization that runs a small rural bingo game that had just been licensed for a local casino slot (meaning that it would not qualify again for two years), raising $\$ 20,000$. It raised about $\$ 38,000$ a year from bingo, mostly used to fund core costs such as cleaning supplies, insurance, office supplies, rent, repairs and maintenance. Bingo thus remains significant even in the province renowned for charitable casino gaming.

In contrast, Ontario charities cannot directly fundraise from casino gaming. ${ }^{20}$ Instead bingo remains the dominant form of charitable gambling. Of 8,512 charitable gaming licenses issued to organizations in Ontario in 2010-11, 8,036 were for bingo (Canadian Partnership for Responsible Gambling 2012, 5). In 2010-11 the net revenue flowing to Ontario charities from bingo was $\$ 43$ million; Alberta charities received $\$ 3.7$ million (compared to $\$ 67.2$ million from casinos) (12). In 2010 Ontario bingo halls were visited by 10.4 million people - more than visit the iconic $\mathrm{CN}$ tower in Toronto - and over 3,000 charities and non-profits raised money through bingo, funding activities ranging from youth ice hockey clubs to support services for victims of violence. Over 60,000 volunteers were involved in running games (field notes from 2011 presentation charities by Ontario Charitable Gaming Association).

Provincial variation in regulatory approach notwithstanding, the general pattern within charitable bingo has been of a steady decline. Bingo boomed in many provinces in 
the 1980 s as associations of charitable licensees opened facilities, often in alliance with businesses to whom they paid rent and various expenses. Bingo halls seating 800 people were regularly filled to capacity. However the game has declined since then, with halls closing and attendance falling. Lower attendance means lower prize pots - a vicious circle. Some charities that were making $\$ 3,000$ on their monthly bingo event in the early 1990s now make almost nothing - one group estimated revenues of $\$ 60$ or $\$ 70$ in quiet months. Alberta's linked bingo game used to run in over 100 halls; it now runs in 56, since "the other ones have just disappeared, gone out of business" (A002).

Provincial governments are often blamed for this decline. Many have turned to s.207 (1) (a) gambling to raise revenue, via casinos, slot machines, and race tracks, with negative effects on charitable bingo. As Katherine Scott (2003) notes "When one of four Ontario casinos was built in Thunder Bay, it put the existing charitable bingos out of business" (10). Charities have sometimes turned to courts to protect their interests (n15) and, as a result, much of the limited legal debate that has occurred in courts about bingo regulation in Canada has focused on the clash between provincial and charity interests in gambling revenues (see summary in Bedford 2013).

However, several provincial governments in Canada have launched bingo revitalization initiatives aiming to bring charities, bingo businesses, and regulators together to revive the game. The Alberta Gaming and Liquor Commission (AGLC) conducted an early review of Alberta's bingo industry in 1998, via a Bingo Review Committee made up of representatives from the provincial government's gaming regulator, the charitable sector, and the bingo industry. ${ }^{21}$ The AGLC now supports Bingo 
Alberta, an organization which works to channel industry concerns to regulators in an attempt to generate a single voice for the sector. The AGLC, in close collaboration with Bingo Alberta, is currently in the early stages of another review of the industry, aiming at revitalization. The key aim is to streamline regulation and simplify the terms and conditions of bingo licenses. Other concerns include the extent to which bingo events which can vary between halls and between areas - should be standardized across the province and how to stimulate increased custom, including by introducing new games and new technology. Moreover the province has authorized private bingo halls, called Class B facilities, where charities have less responsibility to conduct and manage the gaming directly and businesses can take a greater role. One is in existence so far. Otherwise licensed charitable bingo occurs in the remaining 30 association halls (Class A facilities) and some 140 licensed community bingos.

Meanwhile in Ontario in 2005 the Alcohol and Gaming Commission of Ontario (AGCO) launched a Modernization of Charitable Gaming initiative, aiming to modernize regulation to protect charitable revenues and "to reflect the (bingo) industry's changing needs in the $21^{\text {st }}$ century" (AGCO 2009a, 1). It developed a new revenue model for charitable bingo, implemented in 2007 , allowing greater flexibility for charities and hall owners with regard to game timing and mix while trying to preserve charity revenues. The province also piloted electronic bingo in Barrie, Kingston, Peterborough, Sudbury, Toronto, and Windsor, introducing a range of e-gaming. In order that the province complies with s.207 (4) (c) of the Criminal Code (which reserves to provinces the authority to run games requiring a computer), the e-bingo pilot halls moved from AGCO 
to Ontario Lottery and Gaming Corporation (OLG) authority. The OLG - the operational enterprise agency set up to operate gaming services on behalf of the province - thereby assumed responsibility for conducting and managing gambling in the e-bingo sites, taking over from the charities that had operated bingo under s.207 (1) (b) licenses. The pilot is currently being significantly expanded (OLG 2013; Ontario Charitable Gambling Association 2014).

While there has been some disquiet about this strategy, linked to fears that the provincial government would squeeze charities out of bingo (Bedford 2013), in general conflict was minimized through attempts at building consensus between regulators, charities, and bingo businesses. For example the Ontario Charitable Gaming Association was asked by the Ontario Lottery and Gaming Corporation to provide support services to charitable organizations engaged in the new e-bingo halls, and to develop policies, procedures and standards (OCGA 2012/3). In particular, those involved in the e-bingo initiative emphasized that they were seeking "to take charities with us," (field notes from 2011 presentation to charities by OCGA), including ensuring that the revenue gained from e-bingo would still be available for hall charities. They apply for a permit to attend the hall during specified slots to advertise their charity (rather than to run the bingo game) and they receive a share of the profits on this basis. As I show in the remainder of this article, such new closeness between provincial governments and charities has key consequences for volunteers. 


\section{SECTION 3. BONA FIDE SURVEILLANCE: THE LEGAL FRAMEWORK ON VOLUNTEERING IN BINGO.}

Licensed charitable bingo in Canada - and the United States - rests on volunteer labor. It makes gaming profitable for charities and the businesses with which they partner and in Canada it distinguishes charitable gaming events from government-operated gambling conducted under s.207 (1) (a). Striking the correct balance between disciplining and motivating volunteers has thus long been a concern. Ravenscraft and Reilly were worrying in 1977 that those operating charitable bingo games in Ohio (who were supposed to be unpaid) might be unsavory characters, with no real connection to the organization they were representing and maybe even fixing the result. Hence they urged better regulation - via licenses, screening, or at least badges - to prevent abuses (1977, 716). Additionally, as gambling law specialist Donald Bourgeois (2002) notes in relation to Canada, there has long been concern in the charitable gaming sector that some volunteers may be undocumented employees, being paid by the charity and/or the business (which then charges the charity) to staff bingos (433). Charities may have interests in such arrangements if they cannot otherwise produce the volunteers to administer the gaming in their designated slot. Likewise businesses can mitigate the risk of a game being cancelled due to unreliable volunteers. However regulators often regard this arrangement as highly problematic because of the supposed drain on charity resources. One Ontario regulator remarked that such undocumented workers were "parasites, feeding off the backs of charities." An Alberta bingo industry insider noted that during the boom years of the late 1980s and early 1990s, "some of the groups were 
paying volunteers, which was a no-no; you're not supposed to pay anybody; they're supposed to be benevolent. There was a whole raft of that; it went right to the core of that volunteer community." Though she clarified that this was "more minor than major," it remains a widely acknowledged problem.

This distinctive set of concerns must be balanced against another worry common to the volunteer arena generally: labor shortages (Musick and Wilson 2008). It is extremely hard to mobilize people to work bingos. Games are long: a normal evening session will require a volunteer to be present from $5 \mathrm{pm}-10 \mathrm{pm}$, and for a late night session they must work until midnight or later. Most of those interviewed said that it was very difficult for charities to get people to do such work for free. Some rewarded volunteers, with pizza parties, for example, or with food from the concessions. One group that relied heavily on young volunteers rewarded those who gave the most hours with a funded recreational activity and gift certificates. ${ }^{22}$ But problems of burnout, attrition, and funding cuts (resulting in loss of money for pizza, for example) limited the success of such initiatives, leading to persistent worries about volunteer mobilization. Some charities were unable to fulfill their obligations to the hall associations of which they were a part, leading to repercussions such as fines, loss of proceeds, or threats of losing their place at the hall. Others had pulled out of bingo halls altogether.

This tension between regulating and motivating volunteers is evident in the rules that Alberta and Ontario impose on charitable licensees. Regulators in both provinces attempt to monitor the bona fide status of volunteers, to ensure that bingo remains rooted in unpaid labor. In Alberta, charitable bingo games require anything from three to sixteen 
volunteers, but normally run with between eight and fifteen. The positions of bingo chairperson (responsible for the overall operation of the bingo event, supervision of all staff, assigning duties to other volunteers, and ensuring secure handling of cash), paymaster (who supervises the awarding of prizes), and bonanza and special games controller(s) (responsible for special games) "must be filled by volunteers who are bona fide members of the licensed charity" (AGLC 2012, s.7.8). The AGLC's Bingo Terms and Conditions manual defines a bona fide member of a licensed charity as "an individual who is listed or named in the licensed charity's official records as a current member in good standing" (AGLC 2012, s.1.1.1.m; see also AGLC 2006, s.2.6 and s.10). The bingo chairperson is responsible for verifying the identity and source of all volunteers (AGLC 2012, s.7.8.4 b i), including ensuring that the roles requiring bona fide members are staffed by such individuals. ${ }^{23}$ Inspectors from the gaming regulator will check that all volunteers are signed in and wearing name tags and aprons (in accordance with AGLC 2006, s.10.7).

In Ontario, an application for an s.207 (1) (b) charitable bingo license also requires use of bona fide members, defined as:

an active member of an eligible organization in good standing, who has activities within the organization beyond conducting lottery events. "Members of convenience" whose only activity is to assist at lottery events are not considered Bona Fide Members. (AGCO 2006, 1)

The ACGO's terms and conditions for bingo halls require at least three bona fide members "to carry out the activities required for the conduct and management of the 
Lottery or Lotteries for which a Licence has been issued" (AGCO 2013, s.1.4; see also AGCO 2009b, s.3.1). However most association bingo halls use more volunteers per event, often up to twelve. Designated individuals are in charge of and responsible for the conduct and management of the game (AGCO 2009b, s.1.4), including ensuring that the appropriate license is properly displayed, verifying bingo paper and balls, paying out prizes, reconciling accounts, depositing cash, and completing the required reports for the AGCO (AGCO 2011). For some positions, charities have the option of using their own bona fide members, volunteers who are members of the bingo association, or "family, friends or volunteers from other organizations" (AGCO 2006, s.3.2.d). However the latter two types of workers may "receive no remuneration or reimbursement for out of pocket expenses" (emphasis original). Only bona fide members of the licensee may be reimbursed, and then only "for actual out of pocket expenses incurred" (s.9.2a). These expenses are capped at $\$ 20$ per person per event, or 3 percent of the prize board for that event, and they "shall not be paid where it would result in a loss or no profit for the bingo event" (s.9.2b).

The e-bingo halls, under OLG control, have especially strict policies and standards with regard to volunteering. Fewer volunteers are required and they are removed from work around the bingo game. Rather, their role is to provide information about their charity, enhance the "charity feel" of the location so as to distinguish it from s.207 (1) (a) gaming sites, and "promot(e) awareness of how the charitable gaming funds benefit the local community" (OCGA 2012/3, 4). Those who carry out this labor are more strictly regulated than people working in ACGO halls, in part because the role of 
volunteers is crucial to the identity of the gaming centers as benefiting local charities. As explained in the new publication on policies and standards in charitable gaming centers (written by the OCGA):

OCGA has negotiated, on your behalf, an agreement that maintains direct local funds for participating charities. In order to receive these funds, each charitable organization must provide services on-site at the Charitable Gaming Centre and in the local community as required. In order to maintain this important local funding model, it is critical that charities play a very visible and meaningful role in this initiative and are seen to be making a meaningful contribution to the operation. (OCGA 2012/3, 4; emphasis added)

Charities that hold permits to participate in a charitable gaming center are usually required to provide two bona fide member volunteers for the charity's assigned two-hour slot (scheduled for them by a paid coordinator). Furthermore:

In order to achieve customer service excellence a time limit is placed on how long a bona fide volunteer may be in attendance. No charity volunteer will volunteer for more than two consecutive assignments due to the need for breaks and to ensure customer service levels are maintained. (OCGA 2012/3, 7)

In an attempt to eradicate the presence of paid workers seen to be posing as volunteers in bingo halls, the OLG has also introduced new rules to e-bingo halls to restrict the number of charities that volunteers can represent and to improve recordkeeping about volunteers, making it easier to identify and act against people who are suspected of working for pay. These rules exist in the belief that excessive volunteering, 
for too many charities or across too many halls, is evidence that the person is not a genuine volunteer. Charity coordinators in the same area are to share bona fide member lists (s.5c).

The standards used to measure whether individual charities with permits to operate in charitable gaming centers are abiding by the policy on volunteering include the following:

a. A bona fide volunteer participating in the Charitable Bingo and Gaming Revitalization model may only volunteer to carry out "assignments" for a maximum of three individual charitable organizations under "permit" in Ontario.

b. Each Charitable organization must provide and maintain a list of trained bona fide members who are oriented to all policies and standards in advance of carrying out scheduled assignments. This list must include the name of charitable organizations with the names of their trained bona fide members and the respective training dates. To keep numbers manageable and to properly facilitate training and customer service standards, the number of volunteers each charitable organization may utilize during a six-month period must be no greater than twenty volunteers. (OCGA 2012/3, s.5; emphasis original)

Moreover, "there will be no remuneration or reimbursement of expenses for volunteers (no honorariums)" (OCGA 2012/3, s.5.e.i). Action can be taken against charities who fail 
to comply with these policies, including withholding all or part of their share of the proceeds (OCGA 2012/3, s.11.c-e) and suspending or revoking a permit.

At a minimum, such rules on volunteer labor show the on-going concerns of regulators to ascertain volunteer status in relation to licensed charities' ability to conduct and manage bingo. But they are more significant than this, since in their implementation they can have sometimes harmful impacts on volunteers. When the new rules on limiting volunteering to a maximum number of three charities were applied to one of the halls piloting e-bingo in Ontario, for example, long-standing volunteers were "fired." This caused one disgruntled ex-volunteer to stage a protest outside the refurbished hall (now under OLG control). Her protest took the form of warning players that the provincial government would be monitoring bingo winnings and off-setting them against welfare benefits. She stood outside announcing this, trying to discourage players from going in. Although the offsetting of winnings against benefits was not part of the plan involved in shifting to OLG control of bingo, ${ }^{24}$ the fear of it reflects a history of gambling surveillance whereby poor people's play has been scrutinized by provincial welfare agencies. Bingo players have long been accused of wasting public funds (Morton 2003, 94) and they have been targeted by the allied power of charity and state in this regard. Consider, for example, Margaret Little's (1995) account of the administration of the Ontario Mothers' Allowance (OMA):

Bingo halls are yet another site where charitable organizations are involved in the moral regulation of single mothers.... Social workers and charity leaders in North Bay and Elgin County have been known to attend bingo events, take account of 
the winners, and then report it to the OMA office. These public and private welfare workers are fondly called the "bingo police." (105)

The volunteer's protest thus perfectly captures the perceived dangers posed to players from bingo reform, even though the dangers posed to volunteers - as irregular workers remain hard to articulate in their own terms.

In the face of such protest, some regulators urged still stricter action. One municipal official, concerned about workers posing as volunteers and, in his eyes, taking away from charities, asked all board members in one association hall to sign a declaration that they were not being paid and that none of their volunteer runners (who check bingo cards) were either. Even though they did, he remained concerned that "there are some people who signed that declaration who shouldn't have." The concern of provincial regulators to ascertain volunteer status filtered down to the municipal level in Ontario, with additional disclosures being required of workers.

Yet, as noted above, such clampdowns must be balanced against the fact that it is extremely difficult to mobilize volunteers to attend bingos. Bingo reformers consequently face a very clear tension: cracking down too hard on volunteers may jeopardize the ability to run the game as a charitable enterprise. Hence compromise solutions have to be found, ones that (ideally) allow charities and provincial governments to mobilize volunteers successfully and retain control over their activities. Two solutions emerge from closer consideration of bingo revitalization initiatives in Alberta and Ontario: credits and reform of volunteer tasks. 


\section{SECTION 4: ALTERNATIVE CURRENCIES OF VOLUNTEER VALUE.}

One key solution to the tension between regulating and motivating volunteers, in both provinces, is some form of bingo credits, where people work bingos as volunteers in part to get reduced fees for accessing a charity's services. Bingo credits tend to be used for children's sports and recreation activities, where fees for participation are often high. Charities providing such activities constitute the dominant sector in the bingo arena. While sport and recreation provision per se is not recognized as a charitable purpose in Canadian law and policy, many organizations tie sports and recreation to another recognized charitable purpose such as education of the young, cultural preservation (i.e., ethnic dancing groups), therapy and relief of suffering for disabled people, or the provision of sports facilities for public use (AGLC 2003; Bingo Review Committee 1999, 63; Canada Revenue Agency 2009). Although in theory the regulatory agencies of each province should review a group's by-laws to see if the membership fees are so excessive as to prohibit participation of ordinary members of the public (AGLC 2004, no. 2.1, s.7.a.iii), in practice some people seeking the charity's services cannot afford the membership fees. Hence parents and grandparents can - and sometimes must - volunteer for bingos in order to reduce the costs of participating, earning credits that they can use to pay partial fees for their children's or grandchildren's sports. In his US-focused research on volunteer motivations Robert Wuthnow (1991) argues that there is a key ethical difference drawn by many people between receiving "paybacks" for voluntary work such as free parking - and doing voluntary work because one calculates getting those benefits (79-80). Bingo credits exist mostly at the calculative end of this spectrum and 
may involve elements of mandated volunteering. For example one youth sports charity interviewed offers parents of children who want to participate in its activities reduced rates if they "volunteer" for the bingo. Another Ontario charity offering swimming to youth explains to interested parents that bingo volunteering is required and it collects three undated checks of CAN\$200 each from them in an attempt to enforce their attendance. Missing a bingo slot means that the check will be cashed (their child will also be banned from the pool). As an Alberta interviewee - who managed bingo volunteers for a charity and who also volunteered herself for another organization - explained:

Respondent: A lot of our volunteers come to us because they're having ... not necessarily having trouble paying for their children's sports but a lot of them ... it's an easy way. Like for me, I work bingo to pay for my son's hockey so it's... (stops).

Interviewer: What are the fees?

Respondent: It depends how old they are. Last year it was ... for him, he was only four going on five, so it was $\$ 120$; this year it's \$200, next year it's $\$ 400$.

Interviewer: A year?

Respondent: Yes, for 18 weeks. We have a shorter hockey season because they're little, but as they get older ... and that's just the registration fee, so it does help for me to work bingos.

Interviewer: So how much can working the bingo, the credit from that, how much can that help you? 
Respondent: For normal bingo I get 50 points which would be equivalent of $\$ 50$ and if I worked a late night it's $\$ 70$. So if I work three or four bingos through the year I can pay for his hockey.

Almost all stakeholders recognize that this system of credits is essential for the game to run. Although some interviewees preferred charities that show they "really care" by having volunteers work without incentives, many others considered credits to be an ethical way of motivating participation. Noting that it was hard for charities to rustle up volunteers, one interviewee explained: "their fees - whether it's school or swim lessons or hockey - they can get a huge reduction in those expenses for their children. So the nice part about bingo is it gives the people that can't afford to put their children into sports, it gives them the opportunity to make sure their kids are in there" (emphasis added). Another interviewee was dismissive of parents who objected to volunteering, saying that if they wanted to access the services being offered they had to "pay the freight." Another felt that the middle-class parents whose children benefited from these sports and recreational facilities should have to do voluntary work to fund them. The latter interviewee (a bingo hall manager and previously a volunteer and player) was critical of the disconnect between many wealthy parents and "the real world" and felt that making them volunteer was a way to anchor them, while also providing them with a legitimate way to "save":

You know now people would just as soon pay the 50 bucks and not bother, they're busy. But you know what: it brings them back to reality I think, volunteering.... A lot of these programs they could never do if they didn't 
volunteer. $\mathrm{XYZ}$ is a primary example.... Every kid in that group has a big fancy jacket and a big fancy hockey bag and a big fancy sweat outfit. Well you know what? If you come and volunteer your time here, buy the kid the big fancy sweat outfit. You've saved that money.

The general acceptance of the credit system notwithstanding, however, it raises a number of concerns including the extent to which volunteering is undertaken voluntarily; whether membership fees are excessive, and relatedly whether participation is open to all and members represent a broad-based group drawn from the community; ${ }^{25}$ and whether the credit arrangements offered are sufficiently distinct from actual payments. Indeed the line between paying and rewarding volunteers is unclear to some who actually have to walk it. As one bingo hall staff member said when I asked "Let's start off first of all with just the mechanics of what you have to do in your job":

My job is to first of all find the bingo volunteers, schedule them. We pay our - we don't pay our bingo volunteers; we reward our bingo volunteers with points which they can use towards paying for hockey, soccer, and any kind of community orientated sports programmes (emphasis original).

Moreover, the credit system downloads one of the key risks of charitable gaming on to volunteers. If the charity cannot mobilize sufficient people to run the game according to the regulations (in theory raising the risk that the game will be cancelled, harming both the charity and the bingo business, but in practice usually requiring a lastminute scramble for volunteers known to the hall who will step in), the charity's own volunteers are charged, in cash. One strategy is to ask for pre-signed checks from 
volunteers, but in other cases volunteers are required to pay fines imposed on a charity by a bingo association or business for missing a game or they must pay a charge to the hall for the cost of finding replacement workers.

Many of these concerns were raised during Alberta's 1999 Bingo Review. A key concern of the provincial government was to establish better control of volunteers in bingo halls, in particular by implementing stricter policies on volunteer credits. The Bingo Review Committee raised the possibility that the system of having people work bingos to earn credits towards membership of charitable organizations might be scrapped. This was, by far, the most controversial element of the consultations. When asked what she recalled about the 1999 Bingo Review, one interviewee replied "Well the biggest thing in there was that they couldn't offer credits .... That's what made it explode, right." Youth sports groups mobilized vigorously to maintain the ability to use credits:

Groups with the most at stake seemed to provide more individual written responses, including verbal submissions. This was evident among swim clubs from across the province. Collectively they realize a large return from bingo and expressed concerns about changes to bingo which might jeopardize this revenue. (BRC 1999, 45)

As a result, the review left credits mostly in place. Credits were distinguished from volunteer reimbursement on the logic that they did not allow individuals to profit personally from working bingos, but rather functioned to support organizations. Because eliminating credits would hurt charities, they should be permitted (BRC 1999, 101). As the Committee's report explained, 


\section{The use of credits should be allowed, but only to offset the cost of registration}

or competition fees in an acceptable charitable activity, such as amateur athletics.

The use of "credits" in bingo has been widespread in the province for a number of years. If at any time credits had been considered to be prohibited, or contrary to bingo policy, the lack of enforcement has resulted in their becoming widespread and in effect legitimizing them through a now common practice.

Such credits should be permitted only to offset reasonable and legitimate costs of participation in an acceptable amateur or non-professional activity determined to be charitable in nature. That is, they should not be used to accumulate compensation or "earnings" to the volunteer beyond such costs. Moreover, credits must be viewed as belonging to the organization, not to its individual members. They are the property of the organization, are not transferable, and possess no cash value.

The practice of requiring volunteers to work at bingo as a condition of membership should be strongly discouraged. (BRC 1999, 89; emphasis original)

In terms of protecting those who needed a charity's services from being coerced into working for free, this was a weak regulatory response. "Strong discouraging" of charities requiring volunteers to work bingos was clearly not going to stop this endemic practice. Thirteen years after the review I spoke to several parents in Alberta who were 
required to work bingos in order to get their children access to sports and recreational activities. Only one had succeeded in arguing against a voluntary labor requirement $-\mathrm{a}$ professional White man who was critical of gambling and who implied the threat of legal action.

In terms of entrenching charity interests in volunteer labor, however, the 1999 reforms were a success, spawning a new set of rules to enhance charity control over the credit process. The current AGLC Terms and Conditions on volunteer expenses and use of proceeds lays out the ways in which "gaming proceeds may be used to reimburse volunteers for approved expenses incurred while working a gaming event." Key provisions include:

6. Volunteers working a licensed event shall not be paid cash, from gaming proceeds or from any other source of revenue, for their services. This includes, but is not limited to:

a) cash payments;

b) association or bingo licensee "vouchers" which can be exchanged for cash; and

c) receiving money, goods or services for personal use....

7. Volunteers working a licensed event may receive credits/points to help offset the cost of registration fees, competition fees and/or travel expenses for an approved charitable activity conducted by the licensee. The credits/points shall:

a) not be redeemable for cash; and 
b) not be used for social/recreational purposes.

8. Volunteers may transfer the credits/points earned from working an event:

a) to other members of the licensed group; or

b) to individuals who are beneficiaries of the group's programs (for example an amateur athlete participating in a structured and developmental sport); or

c) on the approval of the Commission, to other licensees. (AGLC 2012) This system provides for an alternative currency of volunteer credits where the value accumulated by unpaid workers can be stored up for use by charities and can move between organizations (providing the records are properly kept on both ends - see s.10). The value can only circulate in the context of charitable purposes and it cannot be exchanged for cash - although as noted above when volunteers fail to meet their obligations they have to reimburse the organization affected in cash. Neither can credits be exchanged for cash-like goods, such as grocery vouchers. One group had been audited and fined for the latter:

Respondent: What we used to do, and apparently you can't do this, a long time ago we had quite a problem getting volunteers so what we ended up doing was we would give them their voucher, they would take their voucher, come back to us and we would give them a [local supermarket] gift card in exchange. Because we live in a very lowincome neighborhood and sometimes 40 bucks worth of groceries, 60 bucks worth of groceries is huge to people. But you can't do 
that. We rode that horse for as long as we could and then we got audited.

Interviewer: Was it a big fine?

Respondent: No. It made it worth it for that time but now that ... we couldn't continue it because next time we could lose our gaming license and that would be huge to us.

Later, she returned to this issue, still muddled about why the line on volunteer "earnings" was being drawn so as to stop her organization paying people in food vouchers:

Interviewer: If you could change one thing about the way that bingo is regulated, that would make your life easier basically - what would it be?

Respondent: I would say what people can spend their vouchers on - that's huge. We have talked to people so much because people just don't understand why they're so limited. And I agree - I think it should be a little more broader what they can spend their earnings on as a bingo volunteer.

The widespread reliance on credits to sustain volunteering in Canadian bingo sheds light on several key dimensions of volunteer regulation. Notably, credits confirm that meanings of volunteer work may vary considerably from the standard middle-class narrative of volunteering to build a $\mathrm{CV}$, or improve skills, or discover oneself through working with the poor. Most bingo volunteers are doing unpaid work in order to access services for family members. 
Moreover, the regulatory disquiet about allowing volunteers to profit personally from bingo, in the form of cash, has resulted in a situation whereby charities are given better-protected property interests in volunteer credits. There is a clear, dual state-charity interest in the spoils of volunteer labor at work here. The Alberta bingo reforms represented an increased state interest in, and surveillance of, non-regularized workers and they simultaneously bolstered charity power over the volunteers who sustain the game and whose labor defines and legitimizes the province's charitable gaming model. Concerns about economically coerced volunteering are sidelined. With the charities that responded to the province's consultations assumed to represent the community, volunteer interests become harder to articulate: rather, charities speak for them. It is significant in this regard that Alberta's forthcoming bingo review has not thus far prioritized volunteer credit regulation as a key topic. The current standards will, it appears, be left largely unchanged.

\section{SECTION 5. VOLUNTEER TASK REFORM: CUSTOMER SERVICE AND}

\section{APPROPRIATE HATS.}

You know what, I've worked with charities forever and a day and you have some good workers, you have some bad workers, you have people that don't give a rat's. The worst ones are the Daddy Hockey League guys because they don't really want to work, they just want to be here and watch the game on our big screen TVs. (laughs). (Bingo hall manager) 
As noted above the meanings that volunteers attach to their unpaid work vary significantly and volunteering can produce diverse relations with the users of a charitable service. Parsons's (2006) research on charity shop volunteers is of particular significance for charitable bingo, because volunteering is most effective in the game when those same features -a sense of sociality and mutual aid and a localized ethos of helping people with whom there is a perceived common bond - were present. The question of the extent to which bingo players know or care about the charities fundraising at their bingo hall is beyond the scope of this article, ${ }^{26}$ but it is significant that there is, in the most successful halls, a close relationship between volunteers and players. Several of those who work as paid and unpaid staff in bingo halls got involved in the game as players and then became volunteers (usually for their children's sports). Several volunteers (and hall managers) also prioritized the sense of worth and achievement they gained from helping to provide a social space for people to gather, including people perceived as isolated, lonely, and under-served by other leisure providers. For example several mentioned that bingo was important because it helped older and disabled people get out of the house. The sense of "giving back" was profoundly local and about bingo players in addition to, or sometimes instead of, charities.

When there was little perceived commonality between volunteers and players, problems arose. For example, some groups of White, middle-class volunteers were evidently uncomfortable in bingo halls. One interviewee who had to mobilize a group of well-off parents to work Ontario bingos in return for funds for a youth sports group said awkwardly that part of his struggle was to overcome their aversion to the "different sort 
of people in the hall." This aversion was manifest in terms of anti-First Nations racism and class discomfort. Indigenous people constitute a key part of the bingo player base, in urban and rural environments. Conversely White volunteers often predominate in bingo halls. ${ }^{27}$ In some non-reserve halls, some White volunteers were overtly racist to players they perceived to be indigenous and several made disparaging comments about these players in interviews. A volunteer coordinator in a large Ontario urban bingo hall said that many First Nations and Métis players were treated poorly in halls throughout the area and that she had to train her volunteers to treat everyone equally and to be friendly, so as to draw customers.

In terms of class relations, one bingo manager (also a bingo player and, previously, a volunteer) considered that it was good to make middle class parents "connect" to the real world via volunteering, but she lamented the additional work created by those she labeled (laughing) "Daddy Hockey League guys" who were more trouble than they were worth and who upset the customers with their slow sale of tickets and general lack of knowledge about and interest in the game. Another interviewee's version of this "bad volunteer" involved people:

that want to lean up against the window and watch the world go by till the bingo's done (laughs). The ones that are on their cell phones all evening.... Some parents show up to hold up the wall in order to earn their credits.

Interestingly players were more likely to be rude to middle-class volunteers; one such volunteer said that it seemed as if bingo players enjoyed holding power over people to whom they would normally have to be deferential by ordering them around. Players 
could be kind and helpful to unskilled bingo volunteers, especially if they showed willing, were pleasant, and were fast in selling tickets, but if they were haughty, or slow, players would complain loudly. Another volunteer recalled her experience of volunteering in bingo halls as "a nightmare", "jam-packed" with "people lined up to get in and claim their table," bearing "their ugly troll dolls." This woman was impressed by the skill and speed of players, but when asked about the relationship between the volunteers (who were raising money for their neighborhood association) and bingo players, she replied:

Respondent: They were very demanding. They ran us off our feet. They didn't care who we were, as long as we had a handful of bingo tickets. You know, like it's wasting their time because they could manipulate thirty, forty, fifty tickets at once, and they just had us on the move constantly.

Interviewer: So did you enjoy it?

Respondent: No! No, God, no. [laughter]. It was hell, but like I said, we had a purpose in mind.

Despite the general sense in halls that charitable bingo worked best when volunteers were aligned with players and that problems arose when the gaps between them were too large, revitalization initiatives in Alberta and Ontario have tried to widen the distance between the two groups by limiting volunteer contact with players. Some stakeholders involved in Alberta's current bingo revitalization discussions support a standardization of the game in part because of the perceived need to strengthen and 
support a business mentality within bingo. Such individuals regarded it as important to reduce the authority of hall managers who started out as players and volunteers and who one interviewee characterized as "housewives." Instead, he felt, control should be passed to gaming entrepreneurs and "business guys" who could better maximize revenue streams. Whether the business guys had a better understanding of the customer base than the players/housewives was a topic of much debate.

However it is in Ontario's bingo reforms that the most concerted effort has been made to increase the distance between volunteers and players by reforming volunteer task specifications. Charities with permits to fundraise in the e-bingo halls that move to OLG control under the provincial revitalization initiative are required to engage in marketing and public relations activities to promote awareness of their charity and of the gaming center generally. For example under the policy on "promoting awareness of charity contribution":

Charitable organizations are obligated to promote how the funds raised in the Charitable Gaming Centre support the good works they carry out in their community. It is expected that the charity presence is very evident in the Charitable Gaming Centre. This means that when a customer enters a Charitable Gaming facility they (sic) are immediately aware of the presence of charities and have opportunities to become informed as to how the funds raised in the Gaming Centre benefit the local community. This "charity look and feel" distinguishes Charitable Gaming Centres from other gaming facilities. (OCGA 2012/3, 10, s.B.7) 
To comply with such policies, volunteers must be trained in customer service (s.B.8 standards a) and be knowledgeable about their charity and able to answer questions regarding the services it provides in the community (s.B.7 standards b). Aside from this marketing work, which involves sitting at a table to distribute information, volunteers are prescribed narrow roles helping paid staff with support activities such as "assist[ing] in keeping the environment tidy" or directing people to toilets (OCGA 2012/3, 12). They are allowed to "assist in identifying winners for verification by gaming centre staff" but they are not allowed to handle gaming cash so they cannot pay winners (one of the most rewarding parts of working the game). The new work arrangements inspired little enthusiasm: one interviewee told me firmly that time would pass very slowly when sitting behind a table distributing leaflets.

Finally, volunteers in OLG halls are subjected to a "professional dress code" intended to allow them to be identified readily by players (OCGA 2012/3, s.7.h). Although currently most bingo players are regulars and know the volunteers in their hall, the provincial revitalization initiative imagines that bingo halls will become more like casinos, attracting new customers who are unfamiliar to the game. The code also aims to help make halls look smarter. An earlier version of this policy was introduced in the ebingo pilot halls, which initially had a rule on uniforms (black trousers, white shirts) and name badges. However after complaints from volunteers (on the grounds that not everyone owned such clothing and that charities should not be spending money buying it) the rule was relaxed in some halls to a generic smart-casual policy. The current policy 
and standards manual has departed from this compromise solution, detailing the dress code in some depth:

\section{POLICY}

To reflect the professional modern gaming facilities and to provide consistency to the customer base, trained volunteers must look professional and be easy to identify. Within reason, clothing with a charity logo purchased specifically to support the Charitable Bingo and Gaming model is an allowable expense STANDARDS

a) The dress code requirements at a minimum include conservative, dark pants or skirts. Collared shirts or vests with charity identification (logos) are preferred and recommended to increase exposure for the charities participating. If charity identified shirts or vests are not available then white collared shirts may be worn. Either option must include a nametag indicating the first name of the volunteer and the charity (if no logo). All volunteers from the charity should be dressed in the same colour shirts to make them easily identified. Denim jeans, track pants, stretch pants, shorts, tank tops, and sleeveless t-shirts are not permitted. No hats are permitted unless specifically related to the charity uniform (e.g., Shriner's Fez). Baseball caps are not permitted as they distract from a professional look. Footwear should also be tasteful and appropriate to the role of the volunteer. (OCGA 2012/3, s.6)

Failure to comply will result in financial repercussions for charities (s.11.c). If a volunteer violates the dress code, the charity will lose a quarter of its share of the 
proceeds. It will lose half its share if its volunteers fail to show up at all - quite a penalty for the wrong sort of hat.

This new scrutiny of volunteer attire in the name of taste and customer service will likely increase the distance between bingo volunteers and players in a number of ways. Currently most volunteers dress casually, like most players. Jeans, track pants, and baseball caps (for men and women) are commonplace and shoes are usually sneakers, since the volunteers are on their feet a lot and need to get quickly to customers to sell cards or to verify a bingo. This dress is comfortable, in practical terms and in terms of signifying a relaxed sense of belonging with similarly dressed players. Aprons or vests identifying the person as a volunteer are rarely worn. This will change in OLG halls. Volunteers will look more like staff, either wearing charity uniforms or dressing according to professional conventions.

This process of volunteer task reorganization is not professionalization, since in many ways volunteer work is being de-skilled. The process is not strictly one of introducing task formalization either, since bingo volunteers have long had specified tasks under the charitable gaming regulations of both provinces. Rather what seems new here is the increasing control of volunteer contact with players. Charities and provincial regulators are limiting the scope for volunteer/player interaction by reducing the volunteer role to a generic customer service and advertising function. This publicrelations inspired task reframing will increase the distance between volunteers and players, while tying unpaid work far more tightly to charities and to the provincial 
government. A sense of sociality and mutual aid and a localized ethos of helping players, with whom there was a perceived common bond, will likely recede as a result.

\section{CONCLUSION: LESSONS BEYOND BINGO}

Bingo halls are fascinating sites for research. In the case study presented here, I have argued that efforts to revitalize charitable bingo in Canada have involved increased scrutiny of volunteers, reducing their autonomy and giving charities better-protected interests in their unpaid labor. These initiatives have generally failed to protect people who need charitable services from being coerced into working for free. Moreover, bingo volunteers are increasingly being distanced from bingo players by the new regulations. In Ontario they are increasingly being taken away from the actual labor of running the game and are instead mobilized to fulfill public relations tasks, wherein they act as advertisements for the community benefit to be gained from the charity/state/business compact showcased in new gaming centers. The potential for bingo to promote social spaces of mutual aid between players and volunteers will likely decline.

In terms of the game itself, it is important to explore possibilities for other kinds of revitalization involving consultations with volunteers as stakeholders in their own right. For example, greater interest in volunteer experience may foster the potential for regulators to protect unpaid workers better from charities. Regulators may be prompted to scrutinize the charitable status (and associated tax benefits) given to organizations that charge high membership fees, require back-dated checks as a strategy to mobilize 
"volunteers," or use proceeds to provide ever-fancier sports equipment for already privileged children.

However, the concerns at the heart of this article - about the potentially harmful effects on unpaid workers of state/charity schemes to regulate and incentivize volunteering - resonate beyond bingo and are hopefully of benefit to those who have no interest in the case study per se. In this regard, the bingo stream can perhaps make three contributions to the broader river of critical research into the political, social, and economic effects of voluntarism. First, it suggests the need for more socio-legal research into this type of unpaid work, attentive to the complex mix of rules that govern the sector. While many studies have elaborated the organizational context of volunteering and the diverse meanings that unpaid work holds, these can be augmented by curiosity about charity and labor law at relevant levels of government. Attention to the "lowly" level of licensing, standards, codes of practice, and terms and conditions manuals would seem especially important here.

Second, bingo reveals the increasing responsibilities being placed on volunteers to market charity-state projects. With both charities and states increasingly interested in the public relations potential that volunteers are perceived to hold, there is a pressing need to explore how volunteer tasks may be being re-structured by partnerships between states and charities. Comprehensive, critical attention to legislation, licensing procedures, guidelines, and volunteer task management routines within charities is thus required. Rather than framing such inquiry in terms of state capture, colonization, or cooptation, bingo helpfully reminds us that charities must be approached critically as rule makers. 
Their success in speaking for, and over, volunteers is an effect of legal and political arrangements in which they are often powerful agents.

Third, however, as the public protest by a disgruntled ex-volunteer outside an apparently revitalized Ontario bingo hall confirms, charities and states do not exercise full control over the unpaid workers that they seek to use as marketing tools. While it is essential to identify how volunteers are constructed and regulated (by states and charities), bingo also suggests that we can learn much from the episodes of conflict and failure which become visible if we center volunteers as stakeholders. Specifically, in an era of shared charity/state/business commitment to tapping the public relations potential of volunteers, we might expect the counter-marketing of volunteering to become an increasingly important strategy of opposition. As the value attached to unpaid work narratives rises under schemes to market volunteering, charities and states have strong incentives to speak for unpaid workers - but volunteers may also increasingly seek out opportunities to speak for themselves. For example online lists of charities that partner with governments to coerce volunteering have been used in "boycott workfare" campaigns in some jurisdictions, alongside personal stories from volunteers who are critical of charities. ${ }^{28}$ We may expect alternative, non-charity-controlled platforms for storytelling about volunteering to increase. Bingo confirms the value of seeking out those platforms and of being attentive to volunteers as regulatory stakeholders in their own right. 


\section{WORKS CITED}

AGCO. 2006. Lottery License Terms and Conditions. Created 10/06. Doc. Number 4240

B. Toronto: AGCO. http://www.agco.on.ca/pdfs/bi/terms_cond/4240B.pdf (accessed May 15, 2013).

-----. 2009a. AGCO Bingo Revenue Model for Pooling Bingo Halls: One Year Review Results. Toronto: AGCO.

-----. 2009b. Regular and Special Bingo License Terms and Conditions. Created 06/09.

Doc. Number 3011 B. http://www.agco.on.ca/pdfs/bi/terms_cond/3011B.pdf (accessed May 4, 2013).

-----. 2011. Lottery Licensing Policy Manual: Charitable Gaming Event in Pooling Bingo halls. Winter. http://www.agco.on.ca/llpm/en/chap10.pdf (accessed May 4, 2013).

-----. 2013. Terms and Conditions: Charitable Gaming Events Conducted and Managed in Class A and Class B Bingo Halls and Pooling Class C Bingo Halls. http://www.agco.on.ca/pdfs/bi/terms_cond/4241B.pdf (accessed May 4, 2013).

AGLC. 2003. Charitable Gaming Policy Handbook. Eligibility for Specific Groups: Sports Groups. http://aglc.ca/pdf/charitable_gaming/charitable_gaming_policies_handbook.pdf (accessed April 12, 2013).

------2004. Charitable Gaming Policy Handbook. Charitable and Religious Groups: Basic Eligibility. 
http://aglc.ca/pdf/charitable_gaming/charitable_gaming_policies_handbook.pdf (accessed April 12, 2013).

-----. 2006. Bingo Licensee Terms and Conditions: Licensed Bingo Facilities. Form REG/GAM 5532 (October). http://www.aglc.gov.ab.ca/pdf/handbooks/Bingo_Licensee_Terms_Conditions_Li censed_Bingo_Facilities.pdf (accessed March 14, 2013).

-----. 2012. Bingo Terms and Conditions and Operating Guidelines. http://www.aglc.gov.ab.ca/pdf/handbooks/bingo_terms_and_conditions.pdf (accessed March 14, 2013).

BBC. 2012. Prescott Urges Inquiry into Jubilee Work Experience Claims. June 5. http://www.bbc.co.uk/news/uk-politics-18329526 (accessed May 31, 2013).

Bedford, Kate. 2013. Stakeholders in the Charity Game: Lessons on Welfare and Gambling from Case Law on Canadian Bingo Regulation. Unpublished paper under review. Available on request from author.

Belanger, Yale (ed.). 2011. First Nations Gaming in Canada. Winnipeg: University of Manitoba Press.

Bingo Review Committee. 1999. Alberta Bingo Industry Review: Findings and Recommendations of the Bingo Review Committee. Edmonton, AB: Bingo Review Committee.

Bourgeois, Donald. 2002. The Law of Charitable and Not-For-Profit Organizations. 3rd ed. Markham, ON: Butterworths. 
Boycott Workfare. 2014. Boycott Welfare: National Charities. http://www.boycottworkfare.org/?page_id=16 (accessed June 16, 2014).

Brooks, Neil. 2001. The Role of the Voluntary Sector in a Modern Welfare State. In Between State and Market: Essays on Charities Law and Policy in Canada, ed. Jim Phillips, Bruce Chapman, and David Stevens, 166-216. Montreal: McGillQueen's University Press.

Canada Revenue Agency. 2009. Sports and Charitable Registration. CPS-027. http://www.cra-arc.gc.ca/chrts-gvng/chrts/plcy/cps/cps-027-eng.html\#N10227 (accessed June 16, 2014).

-----. 2013. How to Draft Purposes for Charitable Registration. CG-019. http://www.cra-arc.gc.ca/chrts-gvng/chrts/plcy/cgd/drftprpss-eng.html\#N10469 (accessed June 16, 2014).

Campbell, Colin S., Timothy Hartnagel, and Garry Smith. 2005. The Legalization of Gambling in Canada. Ottawa: Prepared for the Law Commission.

Canadian Partnership for Responsible Gambling. 2012. Canadian Gambling Digest 2010-2011. Responsible Gambling Council/Canadian Partnership for Responsible Gambling. http://www.cprg.ca/articles/201011\%20Canadian\%20Gambling\%20Digest.pdf (accessed June 10, 2014).

Christensen, Robert, Richard Clerkin, Rebecca Nesbit, and Laurie Paarlberg. 2009. Light and Dark Sides of Nonprofit Activities and the Rules to Manage Them: The Case of Charitable Bingo. Administration and Society 41 (2): 213-34. 
Cosgrove, James, and Thomas Klassen. 2009. Casino State: Legalized Gambling in Canada. Toronto: University of Toronto Press.

Dolan, Drew, and Jim Landers. 2006. Gambling on an Alternative Revenue Source: The Impact of Riverboat Gambling on the Charitable Gambling Component of Nonprofit Finances. Nonprofit Management and Leadership 17 (1): 5-24.

Dunn, Alison (ed.). 2000. The Voluntary Sector, the State and the Law. Oxford: Hart.

-----. 2008. Demanding Service or Servicing Demand? Charities, Regulation and the Policy Process. Modern Law Review 71 (2): 247-70.

Go 2 Tourism HR Society. 2103. Caution: You Need to Pay Your Interns. http://www.go2hr.ca/articles/caution-you-need-pay-your-interns (accessed May $31,2013)$.

Harring, Sidney. 1977. Class Conflict and the Suppression of Tramps in Buffalo, 18921894. Law \& Society Review 11:873-912.

Horne, Suzanne, and Avril Maddrell. 2002. Charity Shops: Retailing, Consumption and Society. London: Routledge.

INCITE! Women of Color against Violence (ed.). 2007. The Revolution Will Not Be Funded: Beyond the Non-Profit Industrial Complex. Cambridge, MA: South End Press.

Kingma, Sytze. 2008. The Liberalization and (Re)regulation of Dutch Gambling Markets. Regulation and Governance 2:445-58.

Kramer, Ralph. 1981. Voluntary Agencies in the Welfare State. Berkeley: University of California Press. 
Little, Margaret. 1995. The Blurring of Boundaries: Private and Public Welfare for Single Mothers in Ontario. Studies in Political Economy 47:89-109.

Maes, Kenneth. 2012. Volunteerism or Labor Exploitation? Harnessing the Volunteer Spirit to Sustain AIDS Treatment Programs in Urban Ethiopia. Human Organization 71 (1): 54-64.

Mahood, Linda. 2009. Feminism and Voluntary Action: Eglantyne Jebb and Save the Children, 1876-1928. Basingstoke, UK: Palgrave Macmillan.

Maurutto, Paula. 2003. Governing Charities: Church and State in Toronto's Catholic Archdiocese, 1850-1950. Kingston, ON: McGill-Queen's University Press.

Michaud, Jacinthe. 2004. Feminist Representation(s) of Women Living on Welfare: The Case of Workfare and the Erosion of Volunteer Time. Canadian Review of Sociology 41 (3): 267-90.

Miller, Kevin. 1999. Welfare and the Minimum Wage: Are Workfare Participants "Employees" Under the Fair Labor Standards Act? University of Chicago Law Review 66:183-212.

Milligan, Christine, and David Conradson (eds.). 2006. Landscapes of Voluntarism: New Spaces of Health, Welfare and Governance. Bristol: Policy Press.

Ministry of Government Services. 2007. Modernization of the Legal Framework Governing Ontario Not-for-Profit Corporations. Consultation Paper. Policy and Consumer Protection Services Division, Ottawa. 
Morris, Debra. 1999a. Volunteering: a Nice Little Job for a Woman? In Feminist Perspectives on Employment Law, ed. Anne Morris and Therese O'Donnell. 113138. London: Cavendish.

-----. 1999b. Volunteering and Employment Status. Industrial Law Journal 28 (3): 24955.

Morris, Debra, Anne Morris, and Jennifer Sigafoos. 2013. The Impact of the Equality Act 2010 on Charities. Liverpool: Charity Law and Policy Unit.

Morton, Suzanne. 2003. At Odds: Gambling and Canadians 1919-1969. Toronto: University of Toronto Press.

Musick, Marc, and John Wilson. 2008. Volunteers: A Social Profile. Bloomington: Indiana University Press.

National Association of Fundraising Ticket Manufacturers. 2010. Charity Gaming in North America. St Paul, MN: NAFTM.

O’Halloran, Kerry, Myles McGregor-Lowndes, and Karla W Simon. 2008. Charity Law and Social Policy: National and International Perspectives on the Functions of the Law Relating to Charities. Dordrecht Springer.

OLG. 2013. Charitable Bingo and Gaming Revitalization Initiative. http://www.olg.ca/bingo/gaming_initiative.jsp (accessed June 16, 2014).

Ontario Charitable Gaming Association. 2012/3. Revitalization of Charitable Bingo and Gaming Initiative. Policies and Standards for Charities. Toronto: Ontario Charitable Gaming Association. 
-----. 2014. Current News: Revitalizing Bingo Centres in Ontario.

http://www.charitablegaming.com/Public/Current-News (accessed June 16, 2014).

Paarlberg, Laurie, Becky Nesbit,. Richard Clerkin, and Robert K. Christensen 2005. Charitable Bingo in Indiana: Issues and Implications. Nonprofit Management and Leadership 15 (4): 433-48.

Parsons, Liz. 2006. The Voluntary Spaces of Charity Shops: Workplaces or Domestic Spaces? In Landscapes of Voluntarism: New Spaces of Health, Welfare and Governance, ed. Christine Milligan and David Conradson, 231-45. Bristol: Policy Press.

Pearce, Jone. 1993. Volunteers: The Organizational Behaviour of Unpaid Work. London: Routledge.

Pennsylvania Gaming Control Board. 2007. Study to Determine the Feasibility of Implementing Methods for the Interception of Gaming Winnings of Individuals who are Delinquent Child Support Obligors or Tax Delinquent. Harrisburg: Pennsylvania Gaming Control Board.

Phillips, Jim, Bruce Chapman, and David Stevens (eds.). 2001. Between State and Market: Essays on Charities Law and Policy in Canada. Montreal: McGillQueen's University Press.

Phillips, Susan. 2012. Canadian Leapfrog: From Regulating Charitable Fundraising to Co-Regulating Good Governance. Voluntas 23:808-29. 
Phillips, Susan, and Steven Rathgeb Smith (eds.). 2011. Governance and Regulation in the Third Sector: International Perspectives. London: Routledge.

Prochaska, F. K. 1977. Charity Bazaars in Nineteenth-Century England. Journal of British Studies 16 (2): 62-84

Ravenscraft, Patricia, and Elizabeth Reilly. 1977. Perspectives on Ohio Bingo Regulation: An Historical Analysis and Proposals for Change. Akron Law Review 10 (4): 646-728.

Rekart, Josephine. 1993. Public Funds, Private Provision: The Role of the Voluntary Sector. Vancouver: University of British Columbia Press.

Rochester, Colin, Angela Ellis Paine, and Steven Howlett. 2010. Volunteering and Society in the Twenty First Century. Basingstoke, UK: Palgrave MacMillan.

Scott, Katherine. 2003. Funding Matters: The Impact of Canada's New Funding Regime on Nonprofit and Voluntary Organizations: Summary Report. Ottawa Canadian Council on Social Development/Coalition of National Voluntary Organisations.

Sills, David. 1957. The Volunteers: Means and Ends in a National Organization.

Glencoe IL: Free Press.

Skocpol, Theda. 2003. Diminished Democracy: From Membership to Management in American Civic Life. Norman: University of Oklahoma Press.

Stewart, Andrew, and Rosemary Owens. 2013. Experience of Exploitation? The Nature, Prevalence and Regulation in Unpaid Work Experience, Internships, and Trial Periods in Australia. Report to the Fair Work Ombudsman. Adelaide: Adelaide Law School. 
Tillotson, Shirley. 2008. Contributing Citizens: Modern Charitable Fundraising and the Making of the Welfare State, 1920-66. Vancouver: University of British Columbia Press.

US Government. 2014. Public Service and Volunteerism.

http://www.usa.gov/Citizen/Topics/PublicService.shtml (accessed June 16, 2014).

Valverde, Mariana. 2011. Seeing Like a City: The Dialectic of Modern and Premodern Ways of Seeing in Urban Governance. Law and Society Review 45 (2): 277-312.

Volunteer Canada/Public Safety Canada. 2012. The Screening Handbook. Ottawa:

Volunteer Canada/Public Safety Canada.

White, J. Mark, Kitty Rogers Brown, and Bevan Dowd. 2010. Bingo in Alabama: More than Just a Game. Cumberland Law Review 41:509-32.

Williams, R. J., Belanger, Y. D., \& Arthur, J. N. 2011. Gambling in Alberta: History, Current Status, and Socioeconomic Impacts. Final report to the Alberta Gaming Research Institute, Edmonton, AB. April 2, 2011.

Wilson, John. 2000. Volunteering. Annual Review of Sociology 26:215-40.

------ 2012. Volunteerism Research: A Review Essay. Nonprofit and Voluntary Sector Quarterly 41 (2): 176-212.

Wolch, Jennifer. 1990. The Shadow State: Government and Voluntary Sector in Transition. New York: The Foundation Center.

Wuthnow, Robert. 1991. Acts of Compassion: Caring for Others and Helping Ourselves. Princeton, NJ: Princeton University Press. 


\section{CASES CITED}

Alamo Foundation v. Secretary of Labor, 471 U.S. 290 (1985)

Archie v. Grand Central Partnership, Inc. et al., 95 Civ. 0694 (SS), 1998 WL 122589

(S.D.N.Y.)

Bingo City Games Inc. et al. v. B.C. Lottery Corp. et al., 2005 BCSC 25

Gosselin v. Québec (Attorney General), 2002 SCC 84, [2002] 4 SCR 429

Nanaimo Community Bingo Association v Attorney General of British Columbia, 1998 BCSC 1192

$R$ (on the application of Reilly and Wilson) and the Secretary of State for Work and Pensions [2013], UKSC 68; [2014] 1 All E.R. 505.

Xv Mid-Sussex Citizens Advice Bureau [2012], UKSC 59 UK; [2013] 1 All E.R. 1038.

\section{STATUTES CITED}

Canadian Criminal Code (R.S.C., 1985, c. C-46).

Charitable Uses Act, 1601 (43 Eliz. 1 c. 4).

Indian Gaming Regulatory Act, 1988, Public Law 100-497, 25 U.S.C.

Jobseekers (Back to Work Schemes) Act 2013, c.17.

Ontario Works Act 1997, S.O. 1997, c.25. 


\section{ENDNOTES}

${ }^{1}$ A charity with a contract for job training under the coalition government's increasingly punitive welfare regime used unpaid workers to help steward the celebrations. The "volunteers" - long term unemployed people - were delivered to London late at night and left to shelter from the rain under Thames bridges until their labor was required for the parade the next morning (BBC 2012).

${ }^{2}$ Of those surveyed, 8.5 percent said that they played bingo; 5.7 percent played casino table games (Canadian Partnership for Responsible Gambling 2012, 17).

${ }^{3}$ See Wilson $(2000,2012)$ for a discussion of the evidence in this regard.

${ }^{4}$ In the UK the New Labour government launched a national compact with the voluntary sector in 1998 (Morris 1999b). It also expanded the categories of activity legally defined as charitable (Dunn 2008; O’Halloran, McGregor-Lowndes, and Simon 2008).

${ }^{5}$ See, further, Brooks (2001); Scott (2003); Ministry of Government Services (2007).

${ }^{6}$ In 1957 Sills noted that volunteers resented over-bureaucratization (1957, 33). See also Skocpol (2003) on the 1960s shift in the United States from mass membership voluntary associations to managerially-directed, expert-led advocacy and lobbying groups.

${ }^{7}$ On the UK see $R$ (on the application of Reilly and Wilson) and the Secretary of State for Work and Pensions [2013], UKSC 68; [2014] 1 All E.R. 505; wherein two workfare participants successfully challenged the Jobseeker's Allowance Regulations, 2011 which imposed benefit sanctions on people who failed to meet unpaid work requirements. The 
coalition government fast-tracked emergency legislation through Parliament to nullify the effects of this ruling (see Jobseekers (Back to Work Schemes) Act, 2013, c.17). On Canada see Gosselin v. Québec (Attorney General), 2002 SCC 84, [2002] 4 SCR 429, involving a challenge to Québec's work requirement for benefits recipients. Several other provinces, including Alberta and Ontario, also enacted workfare schemes as part of welfare reforms: e.g. the Ontario Works Act (1997, S.O. 1997, c.25). On the United States, see Miller (1999) on the workfare requirements in the Temporary Aid to Needy Families Act. See also Archie v. Grand Central Partnership, Inc. et al., 95 Civ. 0694 (SS), 1998 WL 122589 (S.D.N.Y.), involving the employment of homeless persons in New York's Pathways to Employment Program.

${ }^{8}$ On the myth of the autonomy of the charitable sector see Skocpol (2003) on the key role played by government in the rapid expansion of voluntarism in the post-civil war United States; Harring (1977) on the role of Buffalo's Charities Organization Society in the police repression of local labor movements in the late 1800s in the interests of business owners; Maurutto (2003) on how philanthropic institutions have long modelled themselves on capitalist enterprises; Rekart (1993) on the intertwining of state and charity in BC; and Wolch (1990) on voluntary organizations as a "shadow state." ${ }^{9}$ E.g., Alamo Foundation v. Secretary of Labor, 471 U.S. 290 (1985), where the US Supreme Court found that workers in the businesses of a non-profit religious foundation were employees for the purposes of the Fair Labor Standards Act and were hence covered by minimum wage and overtime provisions. The workers were mainly indigent people offered "rehabilitation" through the foundation. They worked for little or no pay 
and were punished for poor job performance or absence, including via withholding of food.

${ }^{10}$ On the UK see $X v$ Mid-Sussex Citizens Advice Bureau [2012], UKSC 59 UK; [2013] 1 All E.R. 1038 where the UK Supreme Court held that a disabled volunteer fell outside the scope of UK and European anti-discrimination law. Leading UK charity law specialists note that, while welcomed by many charities, this "does not send the right message to charities in their dealings with the huge army of volunteers upon which many rely" (Morris, Morris, and Sigafoos 2013, 161).

${ }^{11}$ Volunteers often fail the employee test because specific exemptions have been made for charitable organizations. Even when they have not, courts are generally reluctant to probe deeply into labor relations in charities: as Stewart and Owens note in relation to Australia, "generally it has been difficult to perceive a strong policy approach to the interpretive task performed by courts [about whether an employment contract exists for unpaid workers] (absent perhaps a reluctance to find employment relations in relation to charitable, religious, or sporting organisations)." (Stewart and Owens 2013, xvi; emphasis added). However, in Canada some volunteers (especially fire fighters) have been considered employees for the purposes of provincial employment legislation and insurance and worker's compensation benefits (Volunteer Canada/Public Safety Canada 2012). A variety of groups offer legal advice to charities and businesses to reduce this "risk" that volunteers inadvertently become employees. See Go 2 Tourism HR Society (2013). 
${ }^{12}$ In 2011 I attended a day-long seminar for non-profit organizations on Canadian charity law which returned several times to this issue. See also Morris, Morris, and Sigafoos (2013) on UK charity concerns about equality law.

${ }^{13}$ E.g., see Nanaimo Community Bingo Association v Attorney General of British Columbia, 1998 BCSC 1192; Bingo City Games Inc. et al. v. B.C. Lottery Corp. et al., 2005 BCSC 25; and the analysis in Bedford (2013).

${ }^{14}$ More recently see Christensen et al. (2009); Bedford (2013).

${ }^{15}$ E.g., the Seminole tribe legally contested the state of Florida's attempts to restrict highstakes bingo games on its land, prompting litigation that resulted in the 1988 Indian Gaming Regulatory Act (Pub. L. 100-497, 25 U.S.C), the federal legislation that governs state-tribe gaming compacts in the United States. Bingo also played a key role in the conflict over gambling and jurisdiction in the Mohawk territory of Akwesasne, one result of which was the establishment of Internet gaming services on the Kahnawá:ke reserve. On First Nations gambling in Canada see, inter alia, Belanger (2011). ${ }^{16}$ See the current guidance from the Canada Revenue Agency (2013). See Bourgeois (2002) and J. Phillips, Chapman, and Stevens (2001) for analyses of Canadian case law on charitable purposes, including on the extent to which Canadian charities can engage in political activity and on the legal test of whether activities have a public benefit.

${ }^{17}$ Service clubs typically donate 207 (1) (b) proceeds to charitable organizations, although they can fundraise for their own charitable activities if they fulfil the licensing conditions (Bourgeois 2002, 438). Catholic and Jewish congregations typically use bingo proceeds for the public benefit dimensions of religious activity. 
${ }^{18}$ In Ontario, municipal regulators in charge of gaming licensing sometimes fulfil this function, especially in smaller towns where hall associations may lack capacity. ${ }^{19}$ For a history of Ontario's charitable gaming regulation see, inter alia, Bourgeois (2002). For Alberta see Williams, Belanger, and Arthur (2011). For Canada overall see Campbell, Hartnagel, and Smith (2005); Morton (2003); Cosgrove and Klassen (2009). ${ }^{20}$ Charities can apply to the provincial government for grants available from s. 207 (1) (a) revenue.

${ }^{21}$ It recommended that the province improve oversight of charitable purposes, imposing a new requirement that organizations show their need for funds and their record of delivering charitable programs on their license application (Bingo Review Committee 1999, 61).

${ }^{22}$ On the broader use of expenses and perks as motivational tools for volunteers, see Rochester, Paine, and Howlett (2010); Wuthnow (1981); Musick and Wilson (2008). ${ }^{23}$ There are different rules governing which positions must be filled by volunteer staff in association halls and the one private (Class B) facility: see AGLC (2012), s.7.3.1 and s.7.4.1.

${ }^{24}$ The tactic of off-setting gambling winnings against benefits, or using winnings to recoup delinquent child support payments, has been used by governments running casinos and lotteries in some North American jurisdictions - see Pennsylvania Gaming Control Board (2007) for a summary.

${ }^{25}$ These are key factors in deciding whether an organization's purposes and activities are charitable in terms of offering benefits to the community. 
${ }^{26} \mathrm{I}$ address it in a separate piece.

${ }^{27}$ Charities run by White parents, often organizing for their children's sports, can even dominate in on-reserve bingo halls, often because charities have been "grandfathered in" from off the reserve. As a result, eligible First Nations community organizations may be unable to get a bingo fundraising slot.

${ }^{28}$ On the UK see Boycott Welfare (2014). This organization places charities before companies in its list of organizations that are partnering with the coalition government's "workfare" initiative. 